\title{
Associations between polymorphism of the steroid 21-hydroxylase gene (CYP21) and litter size of Polish Large White $\times$ Polish Landrace sows* (short communication)
}

\begin{abstract}
The identification of genes or markers associated with reproductive traits in swine is an important area of research because of the large economic impact these discoveries could have on the swine industry. The steroid 21-hydroxylase (CYP21) gene is located on chromosome 7 in the middle of the swine leukocyte antigen class (SLA) is regarded as a "candidate - gene" reproduction traits. Associations between polymorphism of the steroid 21-hydroxylase gene (CYP21) and litter size of Polish Large White $\times$ Polish Landrace sows were analysed. The 21-hydroxylase genotypes of all 286 animals were determined using a PCR-RFLP procedure. The frequencies of genotypes and alleles of CYP21/NciI and CYP21/HaeIII were follows: 0.077 - AA, $0.308-\mathrm{AB}, 0.615-\mathrm{BB}$ and

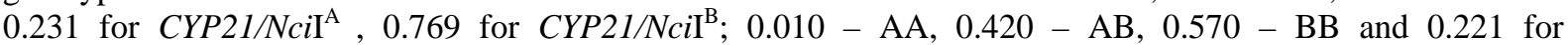

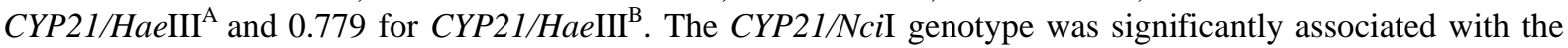
total number of piglets born, born alive and alive at weaning in the 5th - 10th parities. The sows with BB genotype had significantly $(\mathrm{P} \leq 0.01)$ higher level of traits than the animals with $\mathrm{AB}$ genotype. Analysis of reproductive traits in dependence on CYP21/NciI genotypes showed the statistically significant differences $(\mathrm{P} \leq 0.05)$ in number of piglets died before the day of weaned in 2-4 parities. The lowest value of this trait was found for the sows with the AB genotype (2.05\%), while the highest - for the pigs with BB genotype (3.54\%). Associations between CYP21/HaeIII and reproduction traits were not observed.
\end{abstract}

Key Words: 21-hydroxylase gene, pig, litter size, polymorphism

\section{Zusammenfassung}

Titel der Arbeit: Zusammenhänge zwischen dem Polymorphismus von Steroid-21-Hydroxylase-Genen (CYP21) und der Wurfgröße bei Sauen des Genotyps Große Polnische Weiße (GPW) $\times$ Polnische Landrasse (PL) (Kurzmitteilung)

Ökonomische Effekte der Schweinehaltung hängen vom Erfolg der Reproduktionsprozesse ab, darum stehen Gene und genetische Marker, die Reproduktionsmerkmale beeinflussen, im Mittelpunkt des Interesses. Das Steroid-21-Hydroxylase-Gen ist am 7. Chromosom in der Mitte des Komplexes für Antigenübereinstimmung bei Schweinen (SLA) lokalisiert und wird als der für Reproduktionsmerkmale verantwortliche „Kandidat“ angesehen. In den Untersuchungen wurde eine Analyse der Zusammenhänge zwischen dem Polymorphismus des Gens CYP21 und der Wurfgröße der Sauen GWP $\times$ PL durchgeführt. Die Genotypen der Steroid-21Hydroxylase wurden bei 286 Tieren mit PCR-RFLP-Methode bestimmt. Die Gen- und Allelfrequenzen betrugen: $0,077-\mathrm{AA}, 0,308-\mathrm{AB}, 0,615-\mathrm{BB}$ und 0,231 für $C Y P 21 / \mathrm{NciI}^{\mathrm{A}}, 0,769$ für $C Y P 21 / \mathrm{NciI}^{\mathrm{B}}$; $0,010-$ $\mathrm{AA}, 0,420-\mathrm{AB}, 0,570-\mathrm{BB}$ und 0,221 für $C Y P 21 / \mathrm{HaeIII}^{\mathrm{A}}$ und 0.779 für $C Y P 21 / \mathrm{HaeIII}^{\mathrm{B}}$.

Ein signifikanter Zusammenhang zwischen dem Genotyp CYP21/NciI und der Gesamtzahl der geborenen, Zahl der lebend geborenen Ferkel je Wurf und Zahl der abgesetzten Ferkel in den Würfen 5 bis 10 wurde festgestellt. Bei Sauen mit dem Genotyp BB wurde ein höheres Niveau dieser Merkmale als bei Sauen mit dem Genotyp AB beobachtet. Die Auswertung der Reproduktionsmerkmale, je nach CYP21/NciI-Genotyp, wies signifikante Unterschiede $(\mathrm{P}<0.05)$ bei den Ferkeln auf, die die Aufzuchtperiode in den Würfen 2 bis 4 nicht überlebt haben (\% Verluste). Dieses Merkmal war bei den Sauen mit dem Genotyp AB am geringsten (2,05\%) und mit dem Genotyp BB am größten (3,54\%). Die Untersuchungen zeigten keine Zusammenhänge zwischen dem Genotyp CYP21/HaeIII und den ausgewerteten Reproduktionsmerkmalen.

Schlüsselwörter: Steroid-21-Hydroxylase-Gene, Schwein, Wurfgröße, Reproduktion, Polymorphismus

*The project was partially financed by the Ministry of Scientific Research and Information Technology, grant no. 6P06D 01721 


\section{Introduction}

Last years the identification of genes or markers associated with reproductive traits in swine is an important area of research (DROEGEMUELLER et al., 1999; KMIEĆ et al., 2001; SCHLINGMANN et al., 2002; KMIEĆ et al., 2003; MAĆKOWSKI et al., 2004; SCHWARZ et al., 2005) because the large economic impact these discoveries could have on the swine industry. One of the most important enzymatic complexes that take part in the synthesis of adrenal steroids is 21-hydroxylase (CYP21). It takes part in the synthesis of mineralocorticoids and glucocorticoids. It converts the substrates of 17-hydroxyprogesterone and progesterone into 11-deoxycorticosterone, thus leading to the synthesis of cortisol and aldosterone. In human, functional deficiency of the CYP21 gene often results in a life-threatening syndrome (WHITE et al., 1986). In other less dramatic circumstances, it leads to hormonal disturbances such as abnormally high levels of sexual hormones, as found in human and mouse (WHITE et al., 1986, GOTOH et al., 1988). The steroid 21-hydroxylase contains cytochrome P450 reductase and cytochrome $450_{21}$. The deficit of cytochrome $450_{21}$ prevents the synthesis of glucocorticoids and mineralocorticoids and leads to the hypersecretion of adrenal androgens (NEW, 1994). Consequently, alterations in 21-hydroxylase gene may profoundly change the physiology of farm animals and therefore their productivity (GEFFROTIN et al., 1990). The molecular polymorphism in the CYP21 gene was confirmed with the RFLP technique using fragment of swine CYP21 gene as a probe (GEFFROTIN et al., 1991). According to BURGHELLE-MAYEUR et al. (1992) the normal functioning of the CYP21 is essential in the whole life and may significantly affect the expression of certain traits.

The gene encoding 21-hydroxylase (CYP21) is located in the middle of the swine leucocyte antigen class III (SLA) on the short arm of chromosome 7 between the regions SLA class I and SLA class II (GEFFROTIN et al., 1991) which named as "gene - candidate" of swine reproduction traits (ROTHSCHILD and SOLLER, 1997). The porcine CYP21 gene spans about 3050 bp, encodes a protein of 492 amino acids, and like in other species, comprises 10 exons separated by corresponding introns (BURGHELLE-MAYEUR et al., 1992).

The aim of this study was to estimate the allelic frequencies at the porcine CYP2/NciI and CYP21/HaeIII loci and to investigate the relationship of those polymorphisms and reproduction traits of Polish Large White $\times$ Polish Landrace sows.

\section{Materials and Methods}

We examined the association between the CYP21 polymorphism (NciI and HaeIII) and sow reproduction traits in population $\mathrm{F}_{1}$ Polish Landrace $\times$ Polish Large White. All animals were raised at the Kołbacz Farm and mated between 1996 - 2002.

A total of 1596 litter records from 286 sows were used in the litter size analyses. The traits included total number born in litter, number born alive, piglets alive at weaning and $\%$ the piglets born alive but died before weaning.

DNA was isolated from blood samples using MasterPure $^{\mathrm{TM}}$ kit (Epicentre Technologies $\left.{ }^{(\mathrm{R})}\right)$. For genotyping the NciI and HaeIII polymorphism, new primers were designed from the porcine CYP21 sequence (GeneBank accession no. M83939) and using Primer3 software (http://www.genome.wi.mit.edu/cgibin/primer/primer3_www.cgi). The primers: 
NciI F 5'-CTCCCCTAATTGGCACAAAG-3'

NciI R 5'-ATTGCTGAGGTGCTGCGT-3’

were used to amplify a 247-bp fragment.

The CYP21/HaeIII polymorphism designed primers were:

HaeIII F 5'-GACCCAGGAGTTCTGTGAGG-3' and fragment.

HaeIII R 5'-CTCTCTGCCCCAGTTCTTCC-3' and contained 509-bp

The PCR amplification (20 $\mu \mathrm{l}$ final volume) was performed using $90 \mathrm{ng}$ of genomic porcine DNA, $1 \times$ PCR buffer (MBI Fermentas), $200 \mu \mathrm{M}$ each dNTP, 10 pmol each primers (forward and reverse), and $0.6 \mathrm{U}$ Taq polymerase (MBI Fermentas). Conditions were $94^{0} \mathrm{C}$ for 5 min, followed by 30 cycles of $94^{\circ} \mathrm{C} / 30$ s, primer annealing $-60^{\circ} \mathrm{C} / 50 \mathrm{~s}$ and products synthesis $-72^{\circ} \mathrm{C} / 50$ s. The program ended with 5 -min extension at $72^{\circ} \mathrm{C}$ (Biometra T3-Thermocycler). Amplified DNA was digested with 5 $\mathrm{U}$ endonuclease and separated on 2.5 - 3\% agarose gel and visualized under UV light after ethidium bromide staining. Two CYP21 alleles were identified and each animal was classified as either $\mathrm{AA}, \mathrm{AB}$, or $\mathrm{BB}$.

Statistical analysis

Allele and genotype frequencies were calculated according to the Hardy-Weinberg. The expected and observed genotype frequency distributions were compared by Chisquare test.

The litters were grouped by parities: (1) the first parity, (2) 2nd - 4th parity, and (3) 5 th -10 th parities. The traits we compared between the genotypes within each group. The relationship between CYP21 and total number born, number born alive and piglets alive at weaning was evaluated according to one-way analysis, using the following model:

where:

$$
\mathrm{Y}_{\mathrm{ij}}=\mu+\mathrm{a}_{\mathrm{i}}+\mathrm{e}_{\mathrm{ij}}
$$

$\mathrm{Y}_{\mathrm{ij}}$ - analysed trait; $\mu$ - the overall mean; $\mathrm{a}_{\mathrm{i}}$ - the effect of genotype (AA, AB, BB); $\mathrm{e}_{\mathrm{ij}}$ - the random error.

Diferency between genotypes was determined by Tukey test.

Moreover, \% of the piglets born alive but died before weaning was analysed by Kruskal - Wallis test because the trait didnt't have the normally decomposition.

\section{Results}

Digestion of the 247-bp PCR product with $5 \mathrm{U}$ of $N$ ciI (CC $\downarrow$ (G/C)GG) produced fragments that separated on a 2.5\% agarose gel (Gibco BRL) into 205 bp and 42 bp fragments, which were observed for the AA genotype, and 150 bp, 55 bp and 42 bp for the $\mathrm{BB}$ genotype (Fig. 1). 


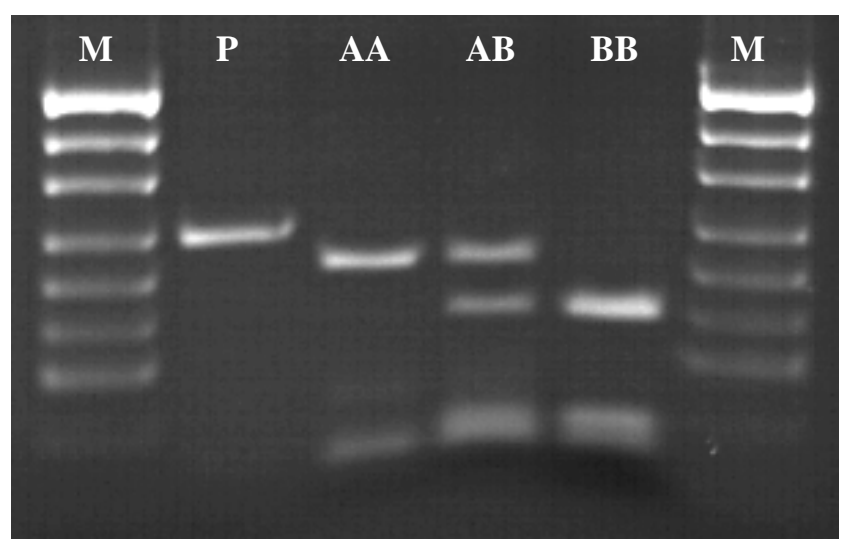

Fig. 1: Representative results of CYP21/NciI analysis detected by agarose gel electrophoresis M - DNA marker (pUC19/MspI); P - PCR product (247 bp) (Elektrophoresebild des Polymorphismus CYP21/NciI M Massenmarker DNA (pUC19/MspI), P - PCR Produkt (247 bp))

Amplified 509-bp fragment of DNA was digested with $5 \mathrm{U}$ of HaeIII (GG $\downarrow C C$ ) and separated on a 3\% agarose gel (Gibco BRL) into $438 \mathrm{bp}$ and $71 \mathrm{bp}$ fragments observed for the AA genotype, and $350 \mathrm{bp}, 88 \mathrm{bp}$ and 71bp for the BB genotype (Fig. 2).

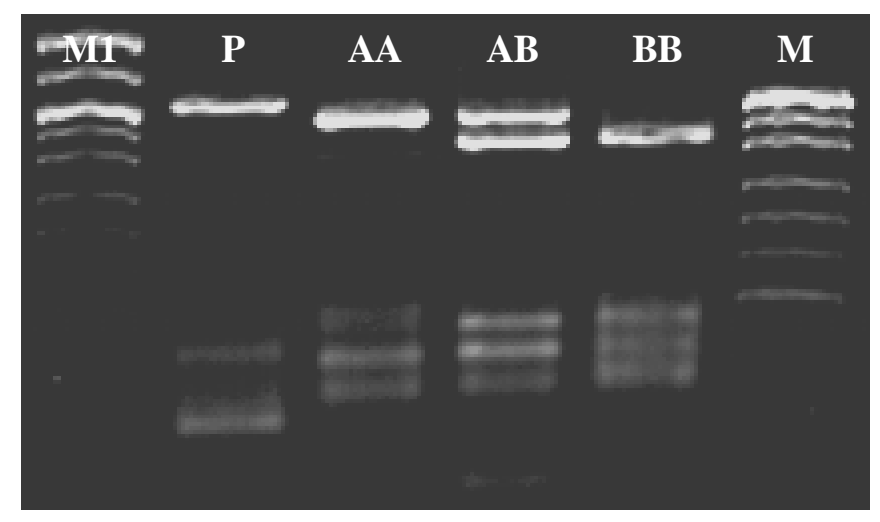

Fig. 2: Representative results of CYP21/HaeIII analysis detected by agarose gel electrophoresis M1 - DNA marker (pUC19/MspI); P - PCR product (509 bp) (Elektrophoresebild des Polymorphismus CYP21/HaeIII M1 Massenmarker DNA (1444), P - PCR Produkt (509 bp))

Genotype and allele frequencies are shown in Table 1.

Table 1

Frequency genotypes and alleles of CYP21 in Landrace $\times$ Polish Large White sows (Frequenz von Genotypen und Allelen von CYP21 bei Polnische Landrasse $\times$ Große Polnische Weiße Sauen)

\begin{tabular}{|c|c|c|c|c|c|}
\hline Polymorphism & \multicolumn{3}{|c|}{ Genotype } & \multicolumn{2}{|c|}{ Alleles } \\
\hline \multirow{2}{*}{ CYP21/NciI } & AA & $A B$ & $\mathrm{BB}$ & $N c i I^{\mathrm{A}}$ & $N c i I^{\mathrm{B}}$ \\
\hline & $\begin{array}{c}0.077 \\
\mathrm{n}=22 \\
\end{array}$ & $\begin{array}{c}0.308 \\
\mathrm{n}=88 \\
\end{array}$ & $\begin{array}{c}0.615 \\
n=176\end{array}$ & 0.231 & 0.769 \\
\hline \multirow{2}{*}{ CYP21/HaeIII } & AA & $\mathrm{AB}$ & $\mathrm{BB}$ & HaeIII $^{\mathrm{A}}$ & HaeIII $^{\mathrm{B}}$ \\
\hline & $\begin{array}{l}0.010 \\
n=3\end{array}$ & $\begin{array}{c}0.420 \\
n=120\end{array}$ & $\begin{array}{c}0.570 \\
n=163\end{array}$ & 0.221 & 0.779 \\
\hline
\end{tabular}


Table 2

Mean values of reproduction traits in reference to CYP21/NciI genotypes of sows (Mittelwerte der Reproduktionsmerkmale in Abhängigkeit vom CYP21/NciI-Genotyp der Sauen)

\begin{tabular}{|c|c|c|c|c|c|c|c|c|c|c|}
\hline \multirow{3}{*}{ Litter } & \multirow{3}{*}{$\begin{array}{c}\text { Genotype } \\
\text { CYP21/NciI }\end{array}$} & \multirow{3}{*}{$\begin{array}{l}\text { Number } \\
\text { of parity }\end{array}$} & \multicolumn{8}{|c|}{ Number of piglets in a litter } \\
\hline & & & \multicolumn{2}{|c|}{$\begin{array}{l}\text { Total number } \\
\text { born in litter }\end{array}$} & \multicolumn{2}{|c|}{$\begin{array}{l}\text { Number born } \\
\text { alive }\end{array}$} & \multicolumn{2}{|c|}{ live at weaning } & \multicolumn{2}{|c|}{$\begin{array}{l}\text { \% died before } \\
\text { weaning }\end{array}$} \\
\hline & & & $\bar{x}$ & SD & $\bar{x}$ & SD & $\bar{x}$ & SD & $\bar{x}$ & SD \\
\hline \multirow{4}{*}{1} & AA & 22 & 7.86 & 2.21 & 7.68 & 2.25 & 7.64 & 2.28 & 0.65 & 3.05 \\
\hline & $\mathrm{AB}$ & 88 & 7.86 & 1.82 & 7.75 & 1.81 & 7.65 & 1.98 & 1.53 & 10.96 \\
\hline & $\mathrm{BB}$ & 176 & 7.85 & 1.87 & 7.61 & 2.12 & 7.48 & 2.05 & 1.48 & 5.25 \\
\hline & Total & 286 & 7.85 & 1.88 & 7.66 & 2.04 & 7.55 & 2.04 & 1.43 & 7.37 \\
\hline \multirow{4}{*}{$2-4$} & AA & 62 & 8.84 & 2.27 & 8.82 & 2.28 & 8.56 & 2.12 & $2.49^{\mathrm{a}}$ & 5.59 \\
\hline & $\mathrm{AB}$ & 226 & 8.98 & 2.09 & 8.90 & 2.08 & 8.68 & 1.95 & $2.05^{\mathrm{ab}}$ & 5.81 \\
\hline & BB & 398 & 9.10 & 2.31 & 9.00 & 2.35 & 8.65 & 2.24 & $3.54^{b}$ & 7.08 \\
\hline & Total & 686 & 9.04 & 2.24 & 8.95 & 2.25 & 8.65 & 2.13 & 2.95 & 6.59 \\
\hline \multirow{4}{*}{$5-10$} & AA & 63 & 9.08 & 1.97 & 8.90 & 2.05 & 8.33 & 2.06 & 6.43 & 8.26 \\
\hline & $\mathrm{AB}$ & 257 & $8.95^{\mathrm{A}}$ & 2.22 & $8.75^{\mathrm{A}}$ & 2.29 & $8.25^{\mathrm{a}}$ & 2.22 & 5.44 & 8.77 \\
\hline & BB & 304 & $9.55^{\mathrm{A}}$ & 2.22 & $9.32^{\mathrm{A}}$ & 2.32 & $8.69^{\mathrm{a}}$ & 2.19 & 6.16 & 7.80 \\
\hline & Total & 624 & 9.26 & 2.21 & 9.04 & 2.29 & 8.47 & 2.20 & 5.89 & 8.25 \\
\hline
\end{tabular}

In Table 2 are the least squares means by CYP21/NciI genotype for the performance test traits. In this study, was observed statistically significant differences between individuals of different genotype CYP21/NciI and all analyzed traits.

For the CYP21/ HaeIII polymorphism, effects of the genotypes are shown in Table 3. The main effect of CYP21/HaeIII genotype was not significant $(\mathrm{P} \leq 0.05)$ for any of the traits analyzed.

Table 3

Mean values of reproduction traits in reference to CYP21/HaeIII genotypes of sows (Mittelwerte der Reproduktionsmerkmale in Abhängigkeit vom CYP21/HaeIII-Genotyp der Sauen)

\begin{tabular}{|c|c|c|c|c|c|c|c|c|c|c|}
\hline \multirow{3}{*}{ Litter } & \multirow{3}{*}{$\begin{array}{c}\text { Genotype } \\
\text { CYP21/HaeIII }\end{array}$} & \multirow{3}{*}{$\begin{array}{l}\text { Number } \\
\text { of parity }\end{array}$} & \multicolumn{8}{|c|}{ Number of piglets in a litter } \\
\hline & & & \multicolumn{2}{|c|}{$\begin{array}{l}\text { Total number } \\
\text { born in litter }\end{array}$} & \multicolumn{2}{|c|}{$\begin{array}{l}\text { Number born } \\
\text { alive }\end{array}$} & \multicolumn{2}{|c|}{ live at weaning } & \multicolumn{2}{|c|}{$\begin{array}{l}\text { \% died before } \\
\text { weaning }\end{array}$} \\
\hline & & & $\overline{\mathrm{X}}$ & SD & $\overline{\mathrm{X}}$ & SD & $\bar{X}$ & SD & $\overline{\mathrm{X}}$ & SD \\
\hline \multirow{4}{*}{1} & AA & 3 & 6.00 & 2.00 & 6.00 & 2.00 & 6.00 & 2.00 & 0.00 & 0.00 \\
\hline & $\mathrm{AB}$ & 120 & 7.75 & 1.87 & 7.61 & 1.89 & 7.53 & 1.86 & 0.83 & 3.84 \\
\hline & $\mathrm{BB}$ & 163 & 7.96 & 1.87 & 7.72 & 2.14 & 7.58 & 2.17 & 1.90 & 9.18 \\
\hline & Total & 286 & 7.85 & 1.88 & 7.66 & 2.04 & 7.55 & 2.04 & 1.43 & 7.37 \\
\hline \multirow{4}{*}{$2-4$} & AA & 4 & 9.50 & 2.52 & 9.50 & 2.52 & 9.00 & 2.58 & 5.00 & 10.00 \\
\hline & $\mathrm{AB}$ & 298 & 9.16 & 2.23 & 9.06 & 2.25 & 8.82 & 2.19 & 2.36 & 6.08 \\
\hline & $\mathrm{BB}$ & 384 & 8.93 & 2.24 & 8.86 & 2.25 & 8.51 & 2.08 & 3.39 & 6.91 \\
\hline & Total & 686 & 9.04 & 2.24 & 8.95 & 2.25 & 8.65 & 2.13 & 2.95 & 6.59 \\
\hline \multirow{4}{*}{$5-10$} & $\mathrm{AA}$ & 9 & 10.78 & 1.79 & 10.33 & 2.18 & 9.22 & 1.79 & 10.12 & 6.93 \\
\hline & $\mathrm{AB}$ & 311 & 9.20 & 2.24 & 8.98 & 2.33 & 8.47 & 2.30 & 5.39 & 7.87 \\
\hline & BB & 304 & 9.27 & 2.19 & 9.07 & 2.25 & 8.45 & 2.10 & 6.27 & 8.63 \\
\hline & Total & 624 & 9.26 & 2.21 & 9.04 & 2.29 & 8.47 & 2.20 & 5.89 & 8.25 \\
\hline
\end{tabular}

\section{Discussion}

A new PCR-based method was developed for the NciI and HaeIII RFLP of the CYP21 gene, as reported by KNOLL et al. (1998). This newly developed PCR - RFLP allowed us to genotype a larger number of animals simultaneously.

The frequency of the CYP21/NciI ${ }^{\mathrm{A}}$ allele in the population of Polish Landrace $\times$ Large White was 0.231 , and was lower than that of the B allele (0.769). Similar frequency of the CYP21/NciI ${ }^{\mathrm{A}}(0.25)$ in Large White breed and $(0.21)$ in Landrace breed was 
observed by KNOLL et al. (1998). The same authors reported lower frequency of the CYP21/NciI ${ }^{\mathrm{A}}$ (0.04) in Pietrain. In the population of the Duroc breed, they have not observed the CYP21/NciI ${ }^{\mathrm{A}}$ allele. The three observed CYP21/NciI genotypes were in Hardy-Weinberg equilibrium.

The CYP21/NciI genotype was significantly associated with the total number born in litter, number born alive, piglets alive in the 5th -10 th parities. The sows with BB genotype had significantly $(\mathrm{P} \leq 0.01)$ higher level of traits than the animals with $\mathrm{AB}$ genotype. Analysis of reproductive traits in dependence on CYP21/NciI genotypes showed the statistically significant differences $(\mathrm{P} \leq 0.05)$ in number of piglets died before the day of weaned in 2-4 parities. The lowest value of this trait was found for the sows with the $\mathrm{AB}$ genotype (2.05\%), while the highest - for the pigs with $\mathrm{BB}$ genotype (3.54\%).

In the case of CYP21/HaeIII, the polymorphism frequency of the A allele obtained in this study (0.221) was similar to that observed by KMIEĆ et al. (2002) in the breeds: Pietrain $\times$ Hampshire (0.210), Pietrain $\times$ Duroc (0.250). Higher frequency of A allele was in the other pig breeds: 0.330 - Pietrain (KMIEĆ et al., 2002), 0.320 - Large White (KNOLL et al., 1998). Analysis of CYP21/HaeIII polymorphism in Polish Large White gave lower frequency of A allele - 0.15 (KMIEĆ and ZIEMAK, 2002; KMIEĆ et al., 2002). In the Duroc breed, the A allele was not observed (KNOLL et al., 1998).

This study has revealed a lower number of sows with AA genotype than expected from the Hardy-Weinberg principle and the difference was significant $(\mathrm{P} \leq 0.01)$.

The main effect of CYP21/HaeIII genotype was non-significant $(\mathrm{P} \leq 0.05)$ for any of the traits analyzed. KMIEĆ and ZIEMAK (2002) obtained a significant $(\mathrm{P} \leq 0.05)$ effect of CYP21/HaeIII genotype for a total number of piglets born alive in the 3rd parity from Polish Large White sows. The animals with BB genotype had a larger litter size (8.98) than those with AB genotype (8.49).

In the current study CYP21 gene was investigated as a potential candidate gene influencing reproduction process. The CYP21/NciI genotype was significantly associated with the total number of piglets born, born alive, alive at weaning and \% the piglets born alive but died before weaning. WILKIE et al. (1999) also found effect of chromosome 7 on some reproductive traits (stillborn piglets, number of corpora lutea and uterine lenght) in a genome-wide scan for QTL in a multiple generation Meishan $\times$ Yorkshire population.

\section{Conclusion}

In the current study CYP21 gene was investigated as a potential candidate gene influencing reproduction process. The CYP21/NciI genotype was significantly associated with the total number of piglets born, born alive, alive at weaning and \% the piglets born alive but died before weaning. WILKIE et al. (1999) also found effect of chromosome 7 on some reproductive traits (stillborn piglets, number of corpora lutea and uterine lenght) in a genome-wide scan for QTL in a multiple generation Meishan $\times$ Yorkshire population.

\section{Acknowledgments}

The author would like to thank all person in Department of Genetics and Animal Breeding and prof. Marek Kmieć for helpful comments. 


\section{References}

BURGHELLE-MAYEUR, C.; GEFFROTIN, C.; VAIMAN, M.:

Sequences of the swine 21-hydroxylase gene (CYP21) and a portion of the opposite-strand overlapping gene of unknown function previously described in human. Biochim. Biophys. Acta 1171 (1992) 2, 153161

DROEGEMUELLER, C.; HAMANN, H.; THIEVEN, U.; KRIETRE, J., DISTL, O.; HARLIZIUS, B:

Influence of the genome region surrounding the estrogen receptor (ESR) gene on litter size in a German Landrace population. Arch. Tierz., Dummerstorf 42 (1999) Special Issue, 175-177

GEFFROTIN, C.; CHARDON, P.; DE ANDRES-CARA, D.F.; FEIL, R.; RENARD, C.; VAIMAN, M.:

The swine steroid 21-hydroxylase gene (CYP21): cloning and mapping within the swine leucocyte antigen complex. Anim Genet, 21 (1990), 1-13

GEFFROTIN, C.; RENARD, C.; CHARDON, P.; VAIMAN, M.:

Marked genetic polymorphism of the swine steroid 21-hydroxylase gene, and its localization between the SLA class I and II regions. Anim. Genet. 22 (1991), 311-322

GOTOH, H.; SAGAI, T.; HATA, J.; SHIROISHI, T.; MORIWAKI, K.: Steroid 21-hydroxylase deficiency in mice. Endocrinology, 123 (1988),1923-1927.

KMIEĆ, M.; DYBUS, A.; TERMAN, A.:

Prolactin receptor gene polymorphism and its association with litter size in Polish Landrace. Arch. Tierz., Dummerstorf 44 (2001) 5, 547-551

KMIEĆ, M.; ZIEMAK, J.:

Preliminary studies on associations between steroid 21-hydroxylase gene (CYP21) and some reproductive traits in pigs. Ann. Anim. Sci., Suppl. 2 (2002), 127-130

KMIEĆ, M.; ZIEMAK, J.; DYBUS, A.; MATUSIAK, S.:

Analysis of relations between polymorphism in steroid 21-hydroxylase gene (CYP21) and quantitative and qualitative characters of boar semen. Czech. J. Anim. Sci. 47 (2002), 194-199

KMIEĆ, M.; KULIG, H.; KONIK, A.:

Preliminary results on association between leptin gene (LEP) and some reproduction performance traits of boars. Arch. Tierz., Dummerstorf 46 (2003) 1, 63-70

KNOLL, A.; CEPICA, S.; STRATIL, A.; NEBOLA, M.; DVORAK, J.:

Numerous PCR-RFLPs within the porcine CYP21 (steroid 21-hydroxylase) gene. Anim. Genet. 5 (1998), 402-403

MAĆKOWSKI, M.; ŚWITOŃSKI, M.; MAĆKOWSKA, J.; PERZ, W.:

Polymorphism of the GPX-5 gene and characteristics of boar semen. Arch. Tierz., Dummerstorf $\mathbf{4 7}$

NEW, M.I.: (2004) 2, 165-171

21-hydroxylase deficiency congenital adrenal hyperplasia. J. Steroid Biochem. Mol. Biol. 48 (1994), $15-22$

PRIMER3 SoftWear: http://www.genome.wi.mit.edu/cgi-bin/primer/primer3_www.cgi

ROTHSCHILD, M.F.; SOLLER M.:

Candidate gene analysis to detect traits of economic importance in domestic livestock. Probe, 8 (1997), $13-20$

SCHLINGMANN, C.; DIETL, G.; RÄDER, I.:

Assoziation von Polymorphismen im Promotorbereich des porcinen HSP 70.2-Gens bei Ebern mit der Wurfgröße. Arch. Tierz., Dummerstorf 45 (2002) 2, 171-180

SCHWARZ, S.; PRESUHN, U.,; KALM, E.; REINSCH, N.:

Characterizing polymorphism and multiplex feasibility of 142 microsatellite markers from a commercial German Landrace line. Arch. Tierz., Dummerstorf 48 (2005) 5, 490-493

WHITE, P.C.; NEW, M.I.; DUPONT, B.:

Structure of human steroid 21-hydroxylase genes. Proc. Natl. Acad. Sci. U S A. 83 (1986), 5111-5115

Received: 2005-01-09

Accepted: 2006-03-14

Corresponding Author

JOANNA ZIEMAK, PhD

Laboratory of Endocrinology, University of Medical Science

ul. Arkońska 4,

71-455 Szczecin

Poland

E-Mail: ziemjoa@tlen.pl 